\title{
Regulating Collaboration: The Legal Framework of Collaborative Governance in Ten European Countries
}

\section{Agnes Batory \& Sara Svensson}

To cite this article: Agnes Batory \& Sara Svensson (2019): Regulating Collaboration: The Legal Framework of Collaborative Governance in Ten European Countries, International Journal of Public Administration, DOI: 10.1080/01900692.2019.1658771

To link to this article: https://doi.org/10.1080/01900692.2019.1658771

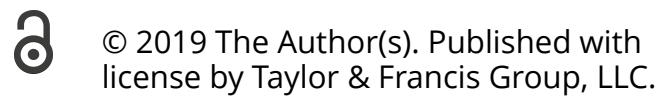

\section{Published online: 03 Sep 2019.}

Submit your article to this journal ¿

$$
\text { Џ Article views: } 112
$$

Q View related articles ¿

$$
\text { View Crossmark data } \longleftarrow
$$




\section{Regulating Collaboration: The Legal Framework of Collaborative Governance in Ten European Countries}

\begin{abstract}
Agnes Batory a and Sara Svensson ${ }^{\mathrm{b}}$ European University, Budapest, Hungary \& School of Education, Humanities and Social Sciences, Halmstad University, Sweden
\end{abstract}

aSchool of Public Policy and Center for Policy Studies, Central European University, Budapest, Hungary; ${ }^{b}$ Center for Policy Studies, Central

\section{KEYWORDS}

Collaborative governance; regulation; EU countries;

legal obligations

\section{Introduction}

There exists a large and growing scholarship on collaborative governance, devoted to studying how collaboration among public, private and societal actors can be enhanced in policy design and service delivery, and how government agencies can work together more effectively. Scholarship has recognized that transformations towards more and better collaboration are not linear or deterministic, and that collaboration takes different forms across countries and time periods. This has given rise to important questions such as where, why and to what extent collaboration actually takes place. A common assumption behind the answers to these questions is that the variation is structured by the institutional context: the decisions actors make are enabled, encouraged or constrained by rules, norms and conventions. Written rules, particularly laws, are one of the most important institutions underpinning the modern state, which makes it all the more surprising that public administration scholarship has largely neglected the legal regulation of collaboration as an important factor. To put it differently, one simple but largely overlooked answer to the question 'why collaborate' is that a formal legal or administrative requirement to do so is in place.

While a small number of American public administration scholars have tackled the issue with respect to the US (e.g., Amsler, 2016; Bingham, Nabatchi, \& O'Leary, 2005; Bingham \& O'Leary, 2015; Freeman, 1997), this kind of mapping exercise has not been done, or has only been done as pertaining to particular policy areas, in the European context. This is the gap in the literature that this article seeks to address, at least as a modest first step. Our objective is to substantiate whether there are requirements to collaborate, and where (in what type of source and context) this obligation applies in ten EU countries (more precisely, nine EU member states and one European Economic Area member). The analysis is comparative: it observes variation across the ten EU/EEA member states in terms of the extent to which requirements or expectations to collaborate are codified in laws and regulations; the nature of the legal infrastructure in terms of scope and content to determine where (in which areas) law and other written rules are concentrated; and finally the broader trends that can be discerned from legal regulation.

Conversely, the article does not seek to elucidate the conditions enabling or obstructing collaboration and reform trajectories, since these have already been subject to extensive analysis (including, notably, Aschhoff, 2018; Emerson, Nabatchi, \& Balogh, 2012; Lægreid, RandmaLiiv, Rykkja, \& Sarapuu, 2014; McGuire, 2006). While this is a clear limitation, more clarity about the legal infrastructure is a precondition for the further development of existing theoretical accounts of collaborative governance. Another caveat is that collaborative government arrangements can be underpinned by both formal institutions (notably, law) and informal practices, as elaborated below. This analysis is confined to codified rules; consequently unregulated practices remain entirely outside our scope.

The article is structured as follows. After a brief discussion of the theoretical background and outline of the 
analytical strategy and research design the methodological approach and the material used are described. The bulk of the article covers the empirical findings in terms of statutory law and then, to a limited extent, guidelines and other 'soft' law. The penultimate section provides a discussion of our country cases in comparative perspective. Finally, a brief conclusion sums up and reflects on the significance of our findings.

\section{Collaborative governance}

The currently most highly cited article on collaborative governance, by Ansell and Gash (2008, p. 544), defines it as '[a] governing arrangement where one or more public agencies directly engage non-state stakeholders in a collective decision-making process that is formal, consensus-oriented, and deliberative and that aims to make or implement public policy or manage public programs or assets.' However, definitions of collaborative governance in scholarship and policy documents vary greatly along several dimensions (Batory, \& Svensson, 2017), most notably whether collaboration involves governmental actors only (internal collaboration), which is how the term is often used by European scholars, or also actors outside the governmental sector, be they citizens, non-governmental organizations or private sector actors (external collaboration), as in the Ansell-Gash definition above (see also Christensen \& Lægreid, 2008).

Many of the most influential definitions involve both the external and internal aspects - and this is how the term is also used below - and suggest overlapping but not identical sets of conditions that facilitate or obstruct collaboration in the two realms. We elaborate elsewhere on what the constraining and enabling conditions might be (); it suffices to refer here to the previously quoted influential article suggesting that they (could) include institutional design; incentives; and prior history of cooperation.

More pertinently for our purposes, conditions helping or hindering collaboration can be embodied in 'hard' and 'soft' institutions (e.g., March \& Olsen, 1989). For instance, consultations with a given organisation or stakeholder may take place regularly because of a legal requirement (hard) but also because the practice is widely accepted and seen as customary (soft). Similarly, administrative traditions (soft), also shaped by New Public Management (NPM) and post-NPM reforms influence what is valued more in public administration: 'getting things done' (managerial public administration) or reaching consensus in a tightly regulated process (procedural public administration) (see e.g. Hammerschmid, Van de Walle, Andrews, \& Bezes, 2016; Thijs et al. 2018). This has implications for the likelihood that collaboration will emerge: in the former case, only if it is seen as essential for reaching a given organisational goal; in the latter, as a matter of course. In any case, hard and/or soft institutions underpin collaborative governance arrangements.

Discussions of the nature of law as an institution are rooted in natural law theory and legal positivism, which will not be covered here. The salient points are, first, that collaboration in law and collaborative practices overlap, but are not identical. Less collaboration might take place than legally required if the law is not implemented or circumvented. Conversely, collaboration with other government agencies or external stakeholders may also be far more extensive than the minimum standard embodied in legislation, when it is so dictated by practical needs such as the inability of individual agencies to address cross-sectoral or 'wicked' problems effectively (e.g., Agranoff \& McGuire, 2003; Christensen, Lægreid, \& Rykkja, 2015; Lægreid \& Rykkja, 2015; Torfing \& Ansell, 2017; van Twist, Kort, \& van der Steen, 2015).

A second salient point is that some (European) countries are systematically less likely to codify rules than others, which however does not necessarily mean that collaborative practices would be less extensive as a consequence. This taps into the distinction between continental European legal systems based on Roman Law and Anglo-Saxon systems based on Common Law. The former is characterised by comprehensive codification ambition and legal specification, the latter by reliance on judicial interpretation (e.g., Kuhlmann \& Wollmann, 2014, p. 11). Codification may also be less likely in countries where coordination and consultation have a long history. In these contexts - such as the Scandinavian countries - collaboration is deeply ingrained in practice, and therefore the adoption of a legal rule may not be seen as necessary. All this is to say that codified rules on collaboration provide necessary but insufficient information for judging how frequently or to what depth governments actually engage in collaborative practices.

As to the role legal regulation does play in collaboration, the literature is relatively scarce, as noted above (as opposed to collaborative law-making, which is relatively well-explored). In the US context, Bingham et al. (2005) pointed out that the legal infrastructure of collaborative practices had been established on the federal level, with relevant legislation rapidly developing on the state level, and sought to situate these developments within public management, governance, and legal studies. Amsler (2016, p. 700) took inventory of the existing legal framework for collaboration at the federal, state, and local levels of US government and concluded that 'future research on collaborative governance should incorporate the legal framework as an important variable' (see also Bingham \& O'Leary, 2015). 
The empirical novelty of this body of literature is providing a comprehensive overview of the legal rules dealing with external collaboration and analyzing their scope and the gaps that appear in regulation. There is also scholarship focusing on specific policy areas, such as environmental law and governance (e.g., Albrecht, 2016; Gunningham, 2009; Mancheva, 2018), or policy practices such as information-sharing (e.g. Lips, Miriam, O’Neill, \& Eppel, 2011). However, in the European (EU) context, work mapping the regulation of collaboration is very limited. When the subject does appear, studies often merely draw on European examples or are confined to particular sectors within a national jurisdiction (e.g., Lang, 2016; Trubek \& Trubek, 2007). In contrast, our study is both explicitly comparative and broad in the sense of not prioritizing one policy area.

\section{Methodology and sources}

The potential information sources for an article on the regulation of collaboration in Europe are almost endless. To focus the analysis, ten countries were selected: Belgium, Denmark, Estonia, France, Germany, Hungary, the Netherlands, Norway, Spain and the UK. The country cases are similar in many respects: notably, EU (or in the case of Norway, European Economic Area) membership means that they are subject to the same or very similar influences from supranational sources. The country cases however also display variation with respect to a wide range of macroinstitutional features that may have a bearing on collaboration. The ten selected countries include examples of all main administrative traditions: Common Law; Roman-Scandinavian; Roman-Germanic; RomanFrench/Napoleonic, and Central and Eastern European (Jamil, Askvik, \& Hossain, 2013; La Porta, Lopez-De Silanes, \& Schleifer, 2008; Meyer-Sahling \& Yesilkagit, 2011; Yesilkagit, 2010). In terms of state structure, the pool includes federal, unitary-centralised and unitary decentralised countries alike; different coordination structures in central government; there is also variation in political culture (adversarial such as the UK as opposed to consensual such as the Netherlands or Norway). This diversity makes the range of cases eminently suitable for comparative analysis by enabling the identification of patterns in codified rules of collaboration and arriving at relatively generalizable conclusions in the EU context.

Data collection, in terms of selecting relevant legal and soft-legal sources, relied on expert opinion. Small teams of academic public administration experts, all members of the consortium of institutions in the project TROPICO - Transforming into Open, Innovative and Collaborative Governments were asked in all ten countries to identify texts pertaining to internal and external collaboration in a range of sources including, but not limited to, constitutions; laws on the legislative process; regulations on the internal structure and working methods of government; ethical and other guidelines for the civil service; and examples of best practice. In addition, the experts were asked to collect documents that relate to data protection/sharing and freedom of information, with a focus on currently valid laws, rules and guidelines affecting how government share data among its different units (internal collaboration) and with stakeholders and the citizenry (external collaboration). The survey of experts resulted in ten country reports and a compilation of 119 primary sources, consisting of statutory law and non-binding but influential guidance documents. These primary sources were then qualitatively and comparatively analysed with the aid of tabular overviews.

Our analytical strategy was, first, to map the extent to which requirements to collaborate were in place and what status these requirements had: e.g., in the constitution, in basic public administration laws, in sectorspecific or other laws, or in documents without legal force, such as administrative guidelines. This corresponds to the degree to which codified rules for collaborative arrangements are formalised and binding, i.e. more or less tightly regulated or only loosely encouraged. Two, the nature of the legal infrastructure in terms of scope and content was analysed, with the aim of identifying where (what type of source) rules were concentrated.

It is important to reflect on the limitations of the methodology and material collected. As discussed above, the collection of codified rules gives us only limited insight into implementation and practice. Moreover, the material collected pertains mainly to the national/central government level, but does not cover sector-specific rules or sub-national levels, with a few specific exceptions (e.g., environmental policy or EU cohesion policy related rules). Finally, the collected material reflects expert judgment on what counted as a relevant source. As is the case with any kind of expert data, there is a risk of bias and distortions that may arise from different interpretations of the key concepts, instructions or questions asked. However, these risks were ameliorated by circulating drafts of a research 
report to the country experts for verification; the findings reported below reflect this cleaned pool of documents and interpretation.

\section{The regulation of collaboration in ten EU countries}

This section reviews the corpus of documents focusing on binding legal regulation. As it will become apparent, not every country is discussed with respect to every type of source, and conversely not every source from a given country report is discussed. These omissions are justified by the aim to pinpoint codified rules that exemplify a pattern (commonalities or differences across counties) or signify a country-specific development, rather than to provide a comprehensive overview which space limitations could not accommodate. The material is presented in line with the hierarchy of laws. By and large, this also means moving from the abstract to the specific, i.e., from general statements of principle to detailed rules on collaboration.

\section{Constitutions}

Constitutions occupy the highest status in the hierarchy of legal sources, but generally have little to say about public administration. As Ginsburg (2010, p. 117) points out, their role is 'to establish the broader structural apparatus of governance and accountability, in which the bureaucracy is the great unspoken'. The principle of collaboration as an explicit requirement features even less in contemporary European constitutions. One simple reason for this is that most constitutions in the ten EU countries in our case study pool date back to times when collaborative governance may have been practiced, but did not enter the vocabulary of legal and administrative sciences or law-makers.

With respect to eight of the countries, the principle of internal and/or external collaboration is therefore implicit in provisions on the basic structure of the state and in rights provided to citizens. The Constitutional Decree of Belgium provides a good example of the former: while is does not discuss coordination by entities within the federal government, it regulates the division of competences across tiers of government with an implied necessity for cooperation among levels involved in particular state functions. This is also the case with the German Grundgesetz. One specific provision (Article 91c (1)) on internal vertical collaboration concerns IT infrastructure and ICT services, which calls for cooperation between the federal government and the Länder. For bills of rights, the Norwegian Grunnlov provides an example of external collaboration required in the sections on the legislative process, which specify hearings where all relevant parties should be consulted as well as a wide range of civil and political rights which can be considered to form the constitutional foundations of external collaboration.

One significant outlier is Spain, where the constitution - adopted in 1978 as the closure in the transition from the Franco regime to democracy - explicitly covers collaboration requirements. In addition to vertical internal cooperation, inferred from the existence and powers of the autonomous communities (regional governments), Article 103(1) refers to coordination among the core principles guiding public administration. The constitution also provides for a wide range of methods for citizens to provide input into the policy process, including a reference to public hearings and consultations in administrative rule-making. The other outlier is the UK which does not have a written constitution, and although it does have constitutional law embodied in other sources we will not review them here.

In sum, constitutions - especially old constitutions are perhaps unsurprisingly silent on or vague about internal and external collaboration, and to the extent the issue is covered, it tends not to be framed as collaboration but rather as an implicit requirement arising from the division of powers, the structure of the state, or the rights of citizens vis-à-vis governments. At least one constitution however explicitly posits collaboration as a guiding legal principle of public administration.

\section{Procedural framework legislation}

There is wide variation in how countries regulate the legislative and administrative process, whether in the constitution itself, in acts of parliament that enjoy quasi-constitutional standing, for instance in terms of a qualified majority requirement for amendments, or in 'regular' laws or regulations that are nonetheless applicable for essentially all law-making and administrative decision-making. Whatever the case, these acts define the basic parameters of the legal infrastructure for collaboration by laying down specific requirements about the range of actors included in policy formulation, decision-making and implementation, and modalities of interaction among them.

In terms of specific regulations of the legislative process, the prime examples come from the two postcommunist countries in our sample. In Hungary, the Acts on the Adoption of Legislation and on Public Participation in Developing Legislation from 2010 can be considered as the most important legal sources regulating external collaboration in policy-making on 
central governmental level - although mainly by providing for consultation rather than more intensive forms of external input. A similar role is played in Estonia by the Guidelines for the Development of Legislative Policy, adopted in 2011 in the form of a Riigikogu (Estonian Parliament) Decision and the Rules for Good Legislative Practice and Legislative Drafting, a regulation of the Ministry of Justice.

Similar 'generic' rules can be found in administrative procedure acts or close equivalents with respect to both internal and external collaboration. (These are analogous with a centrepiece of collaborative governance in the US, the Administrative Procedure Act). These laws regulate and systematize case processing by administrative agencies, and apply to all aspects of public authorities' working procedures. Their main significance is to provide procedural guarantees for citizens and organisations interacting with government as clients/users of public services and parties in regulatory decision-making.

Of the two post-communist countries, Hungary's several times amended Act on the General Rules of Public Administration Procedures and Services from 2004 contains provisions that are relevant for both external and internal collaboration, notably, with respect to electronic communication and case processing. Estonia's Administrative Procedure Act, adopted in 2002 and amended several times, has similar provisions on the competences and jurisdiction of administrative authorities, as well as more extensive coverage of e-government practices than the Hungarian law.

Spain's Law on the Legal Regime of the Public Sector and Law on Common Administrative Procedure of the Public Administrations have very different origins. Adopted in 2015, they enacted key recommendations of the Commission for the Reform of Public Administration, aiming to modernise, streamline and regulate administrative processes. The German Administrative Procedure Act, dating back to 1977, applies to federal authorities and makes explicit reference to horizontal internal collaboration, for instance by regulating the enhancement of information sharing and standardization of administrative procedures. Internal collaboration can be inferred from the Danish Public Administration Act, e.g., in relation to sharing information between administrative agencies. External collaboration appears in the range of procedural requirements for interacting with clients and interested parties. The Norwegian equivalent, adopted in 1967, has a wide scope of application, since it applies to any central or local governmental body engaged in case processing as well as to private persons when exercising public authority on behalf of the state or municipality. The General Administrative Law Act, in force since 1994, plays a similar role in the Netherlands.
The level of detail in the regulation of collaboration in law-making and especially in administrative procedures in these countries reflects the comprehensive codification ambition and legal specification that is characteristic of continental European legal systems. As a general rule, procedural framework laws contain provisions relevant for both internal and external collaboration, but their main significance is to provide guarantees to citizens against arbitrary administrative action.

\section{Laws establishing coordinating bodies}

Much of the legal infrastructure of collaboration involves the creation and regulation of forums for interaction. Given the enormous range of such bodies in every polity, our aim is not to map legal regulation pertaining to them in each of the countries in our case study set, but rather to flag up typical or, in the country expert teams' judgement, particularly important legislation on specific collaborative forums.

In relation to the vertical territorial organisation of the state, organs set up for collaboration across tiers of government play an important role. In Belgium, one of the federal countries in our sample, this role is played by the Consultation Committee and the Interministerial Conferences, as set out in the 'Collaboration and conflict resolution in the federal state of Belgium', a document of the Belgian Parliament. The Committee comprises the prime ministers and a number of ministers from the federal government, the government of Flanders, and the Walloon regional government. Another good example is provided by the $\mathrm{UK}$ in the context of devolution. The Joint Ministerial Committee, consisting of the UK Government and the Scottish, Welsh and Northern Ireland Ministers, was set up in 2013 by a memorandum of understanding among the UK and the devolved administrations. On the level of devolved administrations, legislation sets out the terms, e.g., the Welsh government's relations with local governments in Wales, as codified by the Government of Wales Act of 2006.

Organs set up for vertical collaboration and cooperation across tiers of government may also be sector or task-specific. An example of such a body is Germany's IT Planning Council, which was established by a State treaty in the context of the 2006-09 wave of reforms of the country's federal system. The Council is responsible for steering and coordinating collaborative e-government projects. Legislation setting up sector-specific coordinating bodies is also very common for structuring horizontal internal collaboration in central 
government. There is a wealth of such organs in various policy areas in our country sample. For instance, Belgium's National Security Council, set up by a 2015 royal decree, brings together all relevant actors within the federal government for coordinating intelligence and security policy. In France, 2015 legislative changes in e-governance created two Inter-ministerial Directorates, one for Public Transformation and another for ICT issues. In terms of external collaboration, perhaps the most visible and well-established forums are the organs for social dialogue and interest mediation in line with national traditions of (neo) corporatism or pluralism. Tripartite bodies include, for instance, the Belgian Central Economic Council the Hungarian National Economic and Social Council, the Social and Economic Council of the Netherlands, and the Danish Environmental Economic Council.

The types of laws discussed above are strongly related to the organisation of government - particularly national specificities for inter-ministerial cooperation and the structure of the state, in terms of the number, respective competencies, and interrelationships of tiers of government. For external collaboration, national traditions of interest mediation have a bearing on statutory bodies and their tasks for linking government with organized interests.

\section{Frameworks regulating public administration/civil service as a profession}

The legal and ethical frameworks of civil service as a profession have important implications for individual civil servants' attitudes towards internal and external collaboration. Civil service acts also often contain provisions on the rights of labour unions as external partners and stakeholders. The Norwegian Act on Civil Service gives influence to civil servants' unions over the employment rights of civil servants. Civil service acts also determine categories of civil servants, for instance establishing special rights and responsibilities for the top echelons of officials, as in the case of the Estonian Civil Service Act of 2012. Civil service regulations also often provide for internal collaboration in terms of integrated central services or pooled resources. Spain's Royal Decree 5/2015 revising the Law on the Basic Statute for Public Employees establishes intraservice mobility and integrated human resource management.

Potentially equally importantly, many countries in our sample have codes of ethics or conduct, either generally for the civil service or pertaining to particular categories of officials. While these documents tend not to require collaboration explicitly (with some exceptions), they influence compliance with obligations created by other legal sources. Moreover, by setting high ethical standards in service-orientation, openness, and collegiality, they reflect public administration traditions as they evolve, and should positively influence attitudes to collaboration.

\section{Legal frameworks of public administration reform: strategic planning, modernization, digitalization, and e-government}

Collaborative efforts are often both necessary components and key targets when governments launch significant reforms. These often come as 'law packages', since especially in Civil Law systems such change may require new laws as well as revising and amending existing legislation. This is evident in the French and Spanish approach. First launched in 2005 and followed by several updates, the ADELE and Marianne frameworks aimed to modernise and open up the French public administration through extending the use of new digital tools and other means. This implied amendments of, for instance, Law 2000-321 on citizens' rights in their relationships with public administrations. Around the same time, a Spanish Royal Decree (951/2005) was issued on improving the quality of the general state administration. Recognising that cooperation with citizens was important for quality improvement in the public sector, the decree regulated this framework, including service charters and systems for complaints and suggestions.

A raft of legislation was introduced in all ten countries in connection with digitalisation and e-government 'campaigns'. One example is the Norwegian Regulations on electronic communication with and within the administration, first introduced in 2004 but changed in their entirety in 2014. Recent developments in Germany exemplify a legal response whereby internal vertical and horizontal collaboration was made mandatory. Responding to complaints about fragmented and/or absent online access for citizens and business to administrative services, the Federal Law to Improve Online Access to Administrative Services was adopted in 2017 to force the federal government and the Länder to connect their online portals to one another and improve access to users.

\section{Freedom of information}

Freedom of information (FOI) does not constitute collaboration; at the same time, external collaboration is pre-conditioned by citizens' and non-governmental organizations' ability to inform themselves about 
government agencies' work. Laws on freedom of information are seen as the cornerstone of government transparency. As the Norwegian law, adopted in 1970, stipulates, transparent public administration 'strengthens democratic participation, legal safeguards for the individual, confidence in the public authorities and control by the public'. While rare in the 1970s, a 'global explosion' of FOI laws has been taking place since the late 1980s, taking the current number up to around 100 (Ackerman \& Sandoval-Ballesteros, 2006; Michener, 2011). All countries in our sample guarantee the right to information in their constitutions and/or specific laws. Differences lie in the range of exemptions, e.g. whether internal, working documents are public, and with respect to the range of legitimate interests that justify non-disclosure.

On the other hand, new-generation FOI legislation, such as most of the laws in our sample, also oblige government departments and agencies to proactively disclose a wide range of information, usually electronically on the organisation's website. A specific and particularly important subset of proactive electronic disclosure is sharing, and opening for comments, legislative drafts online, as discussed above. Examples include the Estonian Draft Information System and Home of Citizens Initiatives website; portals for legislative drafts such as the 'Draft bills' section of the UK Parliament's website; or France's digital consultation practice.

\section{Collaboration requirements originating from international legal sources}

Last but not least we should mention codified collaboration requirements adopted due to international legal obligations. Particularly EU law is either directly applicable or influences or necessitates domestic lawmaking. Much of this legislation is sector or policy-area specific. Without trying to cover all policy areas, international obligations are especially influential in the field of environmental legislation. In our set of documents, obligations to consult the public that arise from the Aarhus Convention of 1998 (to which all countries in our sample are signatories) were transferred, for instance, into Belgian domestic legislation as an act of parliament. Another important international undertaking inspiring national legislation is the Open Government Partnership (OGP), a multilateral initiative that aims to secure commitments from governments to promote transparency. Signatories commit to creating an action plan developed with external collaboration arrangements. OGP commitments gained expression for instance in Germany's 2013 Act to
Promote Electronic Government or the Netherland's Act on Open Government. What is apparent from these examples is that collaboration on the EU or international level spills over into national legislation (and practice), thereby constituting a strong positive influence on codification efforts. EU law is particularly important in this respect.

\section{Encouraging collaboration: policy documents and guidelines}

About a quarter of documents collected for this study fall into the broad category of guidelines and policy papers, such as government green papers, white papers, strategy papers and programs preceding legislation. Unfortunately, given the space constraints, a detailed analysis of these documents cannot be included here. Nonetheless, to at least indicate the nature of these sources, they fall into, typically, administrative reform strategies, action plans on digitalization and e-government; guidance for civil servants on engaging citizens; and guidance on public-private partnerships and procurement processes. While these documents lack legal force, they are likely to have a significant impact on collaboration practices - particularly since some countries are generally less likely to enact laws than others, and because much of the operational, organisationallevel regulation of collaborative practices is likely to be laid down in such 'soft' sources.

\section{Comparative analysis}

Based on a qualitative analysis of the corpus of legislation and policy documents, a few observations can be offered about patterns in the regulation of collaboration. Starting with similarities, collaboration is underpinned by an extensive range of legal requirements in all ten countries, although imposing these requirements is generally not the main objective of the legislation. Rather, collaboration requirements are set 'on the side' of the functional objectives of legislative activity although, as noted above, there are a number of significant exceptions to this - and remain on a rather abstract level. Another commonality is that, to a significant degree, collaboration is 'standardised' on agency level by administrative orders or guidelines. However, even there, many documents remain on a relatively general level, stating an obligation of collaboration without going into specific requirements.

There are also commonalities in where (what type of legal source) collaboration is regulated. Most of the countries in the sample imply rather than explicitly prescribe collaboration in constitutional law and, to 
the extent that collaboration can be inferred, it tends to be connected to constitutional principles such as the division of powers, the division of competences across vertical levels of (federal) states, and citizens' rights visà-vis government. Procedural law, either on lawmaking or on administrative procedure, is an area where almost all countries have binding requirements for cooperation with non-governmental actors (e.g., consultations with citizens and stakeholders in lawmaking) as well as for administrative agencies to cooperate with one another in order to effectively serve clients and users. A large body of law on collaboration is situated in legislative acts establishing various coordinating bodies, and in long-standing regulation of public administration/civil service as a profession, particularly in terms of (non-binding) ethical guidelines. Finally, the transfer or transposition of international legal/EU law requirements into national legislation constitutes an important source of requirements for collaboration.

Concerning differences, there is variation across the ten cases in terms of when and with respect to what type of governmental activity collaboration requirements appeared. Some of these differences may be attributed to different trajectories of public administration reform, digitalization, and a visible trend towards (more) open government. For instance, in Denmark, a concern with collaboration is associated with a backlash against NPM reforms, which resulted in calls to turn towards New Public Governance and Public Value Management, and consequently also deeper collaboration across the public sector and with businesses, civil society and citizens. In France, collaborative governance is tied in with legislative activity concerning open government and state modernization.

The analysis of legal and policy documents reveals similar diversity in terms of the focus of the documents. First, in the UK, Estonia, and Norway there are central guidelines on consultation and/or collaboration, examples being the UK Consultation Principles, the Estonian Good Engagement Practices, and the Norwegian Guidelines for collaboration in the public sector. On the other hand, collaboration in France, Denmark and Hungary has been contextualised with reference to overall public administration reform. In France, the most important ways to encourage collaboration has been through broad strategic visions such as the 'Simplification Shock' or the 'Programme on Public Action', ultimately seeking gains in both efficiency and the quality of the citizen's experience through various measures, often focusing on e-government. Spain's regulatory trajectory is relatively similar. Finally, in some countries (e.g. Belgium, the
Netherlands, and the UK), laws and advisory documents regarding contracting out procedures, publicprivate partnerships or citizen co-creation are fundamental to collaborative government regulation.

\section{Conclusion}

In conclusion, this comparative investigation found an extensive range of codified rules of collaboration, concentrated in procedural framework legislation, statutory requirements for consultative bodies; the legislation on civil service as a profession; freedom of information laws and laws requiring public participation; and finally EU/ international legal instruments. Requirements to collaborate can also be inferred from constitutions. Procedural legal acts serve as broad frameworks for external collaboration; in the case of laws on the legislative process, by explicitly requiring the involvement of particular stakeholders or the citizens, and in the case of public administration acts, by setting the parameters of administrative action affecting citizens as clients and users of public services. Civil service regulation and codes of ethics codify normative standards embodied in administrative traditions, and are therefore relevant for both internal and external collaboration. Moreover, the EU is a direct influence in that collaboration requirements from EU law have become part of national legislation.

Some - but not all - of these concentrations/thematic foci of regulation correspond to macroinstitutional variation among European countries. For instance, the structure of the state is the underlying cause for many constitutional rules pertaining to collaboration within government. The vertical distribution of competences in the state as well as the organisation of government horizontally gave rise to legislation establishing bodies for vertical and/or horizontal coordination. National traditions of interest-mediation and social dialogue underpin the laws governing external collaboration involving government, professional associations and trade unions.

However, not everything can be traced back to macro-institutional factors. In our country cases, the most significant drivers for new legislation prescribing collaboration were associated with digitalisation/ICT developments and a shift towards open government. These drivers were often not manifested in law individually but rather bundled together, most notably in public administration reform, enacted as reform packages or reflected in administrative guidance tied to reforms (including, for instance, regulation and guidance on public-private partnerships, contracting out, and simplification, much of which is rooted in New Public Management). 
This is also to say that the national connotations of collaboration vary, reflecting country-specific context in terms of the major aims of reforms. For instance, in France, collaboration is tied with the notion of modernisation and simplification in public administration, both motivated by technological change and a desire to improve citizens' experience of government. In Norway, digitalisation is a leading theme. The situation is similar in Estonia, with added pressure to adapt to EU structures, which was also a factor in Hungary. In the UK, the thrust of change is tied in with devolution, and in Germany and Belgium with regulating the interconnections of levels of government.

At this point, it is important to acknowledge the limitations of this article. As pointed out in the Introduction, a comparative analysis of codified rules alone clearly does not provide a full picture of collaborative governance in European countries. This is partly because, as we have established, there is good reason to expect that collaborative practices abound even when there is no legal requirement in place either because in some countries (notably the UK) legal traditions do not require written rules for all aspects of governmental activity, or because, as in Scandinavia, collaborative practices predate contemporary understandings of collaborative governance. The study also faced the usual trade-off between depth and width in comparative research (Lijphart, 1971). The price of covering 10 countries, if rather superficially, was that many interesting countryspecific details remain unreported - this despite the fact that the data set was limited in terms of jurisdictions (country cases), levels (covering only national central government level, with some exceptions, and not local, regional or supranational) and scope (specific policy areas).

Nonetheless, this article represents a first step towards mapping the legal regulation of collaboration in the European context, which should be useful for further theoretical and empirical research on the topic. More specifically, studies on collaborative frameworks on both EU and sub-national levels as well as in different policy areas or sectors (some more, others less affected by supranational rule-making) would be particularly promising avenues for further research. In general, European scholarship on collaborative governance would benefit from undertaking more comparative analysis, whether in terms of country cases or specific forms of collaboration mandated by law. Finally, further work is clearly needed in uncovering the implementation of regulation on collaboration - i.e., collaborative government practices, to establish how much stakeholders and citizens can actually engage with the policy process and the extent to which government agencies join forces to reach shared public policy objectives.

\section{Funding}

This work was supported by the European Union's Horizon 2020 programme [726840].

\section{References}

Ackerman, J. M., \& Sandoval-Ballesteros, I. E. (2006). The global explosion of freedom of information laws. Administrative Law Review, 58(1), 85-130.

Agranoff, R., \& McGuire, M. (2003). Collaborative public management: New strategies for local governments. Washington D.C: Georgetown University Press.

Albrecht, J. (2016). Legal framework and criteria for effectively coordinating public participation under the floods directive and water framework directive: European requirements and German transposition. Environmental Science \& Policy, 55(Part 2), 368-375. doi:10.1016/j. envsci.2015.07.019

Amsler, L. B., formerly Bingham. (2016). Collaborative governance: Integrating management, politics, and law. Public Administration Review, 76(5), 700-711. doi:10.1111/ puar. 12605

Ansell, C., \& Gash, A. (2008). Collaborative governance in theory and practice. Journal of Public Administration Research and Theory, 18(4), 543-571. doi:10.1093/jopart/ mum032

Aschhoff, N. (2018). Citizens differ from organizations: Modeling a specific citizen-centered collaborative capacity. International Journal of Public Administration, 41(4), 284-296. doi:10.1080/01900692.2016.1263657

Author1 and Author2.

Batory, A., \& Svensson, S. 2017. Literature and Report Review. Available at http://tropico-project.eu/workpackages/work-package-2/

Bingham, L. B., Nabatchi, T., \& O'Leary, R. (2005). The new governance: Practices and processes for stakeholder and citizen participation in the work of government. Public Administration Review, 65(5), 547-558. doi:10.1111/ j.1540-6210.2005.00482.x

Bingham, L. B., \& O'Leary, R. (2015). Big ideas in collaborative public management. London: Routledge.

Christensen, T., \& Lægreid, P. (2008). NPM and beyondleadership, demography and culture. International Journal of Administrative Sciences, 74(1), 5-21.

Christensen, T., Lægreid, P., \& Rykkja, L. H. (2015). The challenges of coordination in National Security Management - the case of the terrorist attack in Norway. International Review of Administrative Sciences, 81(2), 352-372. doi:10.1177/0020852314564307

Emerson, K., Nabatchi, T., \& Balogh, S. (2012). An integrative framework for collaborative governance. Journal of Public Administration Research and Theory, 22(1), 1-29. doi:10.1093/jopart/mur011 
Freeman, J. (1997). Collaborative governance in the administrative state. UCLA Law Review, 45(1), 1-99.

Ginsburg, T. (2010). 'Written constitutions and the administrative state. On the constitutional character of administrative law.'. In S. Rose-Ackermann \& T. Ginsburg (Eds.), Comparative administrative law (pp. 117-127). Cheltenham, UK: Edward Elgar.

Gunningham, N. (2009). Environment law, regulation and governance: Shifting architectures. Journal of Environmental Law, 21(2), 179-212. doi:10.1093/jel/eqp011

Hammerschmid, G., Van de Walle, S., Andrews, R., \& Bezes, P. (2016). Public administration reforms in Europe: The view from the top. Cheltenham, UK: Edward Elgar.

Jamil, I., Askvik, S., \& Hossain, F. (2013). Understanding administrative culture: Some theoretical and methodological remarks. International Journal of Public Administration, 36(13), 900-909. doi:10.1080/01900692.2013.837728

Kuhlmann, S., \& Wollmann, H. (2014). Introduction to comparative public administration: Administrative systems and reform in Europe. Cheltenham, UK: Edward Elgar.

La Porta, R., Lopez-De Silanes, F., \& Schleifer, A. (2008). The economic consequences of legal origins. Journal of Economic Literature, 46(2), 285-332. doi:10.1257/jel.46.2.285

Lægreid, P., Randma-Liiv, T., Rykkja, L. H., \& Sarapuu, K. (Eds..). (2014). Organizing for coordination in the public sector. In Practices and lessons from 12 European Countries. Basingstoke: Palgrave Macmillan.

Lægreid, P., \& Rykkja, L. H. (2015). Organizing for 'Wicked problems' - analyzing coordination arrangements in two policy areas: Internal security and the welfare administration. International Journal of Public Sector Management, 28 (6), 475-493. doi:10.1108/IJPSM-01-2015-0009

Lang, A. (2016). Collaborative governance in health and technology policy: The use and effects of procedural policy instruments. Administration \& Society, 51(2), 272-298. doi:10.1177/0095399716664163

Lijphart, A. (1971). Comparative politics and the comparative method. American Political Science Review, 65(3), 682-693. doi:10.2307/1955513

Lips, A., Miriam, B., O’Neill, R., \& Eppel, E. A. (2011). Crossagency collaboration in New Zealand: An empirical study of information sharing practices, enablers and barriers in managing for shared social outcomes. International Journal of Public Administration, 34(4), 255-266. doi:10.1080/01900692.2010.533571

Mancheva, I. (2018). Which factors spur forest owners' collaboration over forest waters? Forest Policy and Economics, 91(June), 54-63. doi:10.1016/j.forpol.2017.09.002

March, J. G., \& Olsen, J. P. (1989). Rediscovering Institutions. New York, NY: Free Press.

McGuire, M. (2006). Collaborative public management: Assessing what we know and how we know it. Public Administration Review, 66(December), 33-43. doi:10.1111/j.1540-6210.2006.00664.x

Meyer-Sahling, J.-H., \& Yesilkagit, K. (2011). Differential legacy effects: Three propositions on the impact of administrative traditions on public administration reform in Europe East and West. Journal of European Public Policy, 18(2), 311-322. doi:10.1080/13501763.2011.544515

Michener, G. (2011). FOI laws around the world. Journal of Democracy, 22(2), 145-159. doi:10.1353/jod.2011.0021

Thijs, Nick, Gerhard Hammerschmid and Enora Palaric. 2018. A comparative overview of public administration characteristics and performance in EU28. European Commission, Directorate- General for Employment, Social Affairs and Inclusion.

Torfing, J., \& Ansell, C. (2017). Strengthening political leadership and policy innovation through the expansion of collaborative forms of governance. Public Management Review, 19(1), 37-54. doi:10.1080/14719037.2016.1200662

Trubek, D. M., \& Trubek, L. G. (2007). New governance and legal regulation: Complementarity, rivalry, and transformation. Columbia Journal of European Law, 13 (3), 539-564.

van Twist, M., Kort, M., \& van der Steen, M. (2015). Assessing and appraising the effects of policy for wicked issues: Including unforeseen achievements in the evaluation of the district policy for deprived areas in the Netherlands. International Journal of Public Administration, 38(8), 596-605. doi:10.1080/ 01900692.2014.952821

Yesilkagit, K. (2010). The Future of administrative tradition: Tradition as ideas and structure. In M. Painter \& G. B. Peters (Eds.), Tradition and public administration. London: 145-157, Palgrave Macmillan. 